\title{
PROGNOSTIC FACTORS OF SURGICALLY-TREATED PATIENTS WITH CANCER OF THE RIGHT COLON: A TEN YEARS' EXPERIENCE OF A SINGLE UNIVERSITARY INSTITUTION
}

\author{
Fatores prognósticos de pacientes com câncer de cólon direito tratados cirurgicamente: experiência de 10 anos de uma \\ instituição universitária
}

Sergio Carlos NAHAS, Caio Sergio Rizkallah NAHAS, Leonardo Alfonso BUSTAMANTE-LOPEZ, Rodrigo Ambar PINTO, Carlos Frederico Sparapan MARQUES, Fabio Guilherme CAMPOS, Ivan CECONELLO

From the Hospital das Clínicas e Faculdade de Medicina, Universidade de São Paulo (Clinic Hospital and Faculty of Medicine, University of São Paulo), São Paulo, SP, Brazil.

HEADINGS - Colon cancer. Survival. Lymph node.Surgical treatment. Right colectomy.
ABSTRACT - Background: Colorectal cancer is one of the most common malignancies in the world. There are many controversies in the literature about the prognostic value of primary tumor location. Many studies have shown higher survival rates for tumors in the right colon, and worse prognosis for lesions located more distally in the colon. Aim: To analyze the results of surgical treatment of right-sided colon cancers patients operated in one decade period and identify the prognostic factors that were associated with lower overall survival in stages I-IV patients. Methods: A retrospective review from the prospectively collected database identified 178 patients with right-sided colon cancer surgically treated with curative intent. Demographic factors (gender and age), tumor factors (site, T stage, $\mathrm{N}$ stage, $\mathrm{M}$ stage, histological type and tumor differentiation), and lymph node yield were extracted to identify those associated with lower overall survival. Results: Mean age was $65( \pm 12)$ years old, and $105(56.1 \%)$ patients were female. Most common affected site was ascending colon (48.1\%), followed by cecum (41.7\%) and hepatic flexure (10.2\%). Mean length of hospital stay was $14( \pm 2.8)$ days. T stage distribution was T1 (4.8\%), T2 (7.5\%), T3 (74.9\%), and T4 (12.8\%). Nodal involvement was present in $46.0 \%$, and metastatic disease in $3.7 \%$. Twelve or more lymph nodes were obtained in $87.2 \%$ of surgical specimens and $84.5 \%$ were non-mucinous tumors. Mean survival time was $38.3( \pm 30.8)$ months. Overall survival was affected by T stage, $\mathrm{N}$ stage, $\mathrm{M}$ stage, and final stage. Lymph node involvement $(\mathrm{OR}=2.06)$ and stage III/IV $(\mathrm{OR}=2.81)$ were independent negative prognostic factors. Conclusion: Right-sided colon cancer presented commonly at advanced stage. Advanced stage and lymph node involvement were factors associated with poor long term survival.

\author{
Correspondence: \\ Sergio Carlos Nahas \\ E-mail: sergionahas@uol.com.br \\ Financial source: none \\ Conflicts of interest: none
}

Received for publication: 18/09/2014 Accepted for publication: 11/12/2014

DESCRTORES - Neoplasia do cólon. Câncer. Sobrevida. Metástases linfonodais. Tratamento cirúrgico. Colectomia.
RESUMO - Racional: Câncer colorretal é o tipo mais comum das neoplasias gastrointestinais. Há muitas controvérsias na literatura acerca do valor prognóstico do sítio da neoplasia. Muitos estudos revelam maiores taxas de sobrevida para tumores em cólon direito, com piora do prognóstico à medida que as lesões se situam mais distalmente. Objetivo: Analisar os resultados do tratamento cirúrgico de pacientes com câncer de cólon direito estádios I-IV operados em um período de dez anos e identificar os fatores prognósticos que foram associados com menor sobrevida global. Métodos: Em 10 anos, 187 pacientes foram submetidos à colectomia direita com intenção curativa. Foram estudados os seguintes fatores: gênero, idade, localização do tumor, o número de linfonodos obtidos no espécime, comprometimento linfonodal, estádio T e presença de metástases à distância. Estes fatores foram avaliados quanto à possibilidade de serem indicadores prognósticos na sobrevida em cinco anos. Resultados: A idade média foi de $65( \pm 12)$ anos e $105(56,1 \%)$ eram mulheres. A localização, mas comum foi o cólon ascendente $(48,1 \%)$, seguido do ceco $(41,7 \%)$ e o ângulo hepático (10,2\%). A média de tempo de internação hospitalar foi $14( \pm 2.8)$ dias. A distribuição do estádio T foi T1 $(4,8 \%)$, T2 (7,5\%), T3 (74,9\%) e T4 (12,8\%). Acometimento linfonodal ocorreu em $46,0 \%$ e metástases à distância em 3,7\%. Um mínimo de 12 linfonodos ressecados foram obtidos em 87,2\% dos espécimes cirúrgicos. Em $84.5 \%$ os tumores eram não-mucinosos. A média de sobrevida foi de $38,3( \pm 30.8)$ meses. A sobrevida geral foi afetada pelo estádio T, N, M e pelo estádio final. O acometimento linfonodal $(R R=2,06)$ e os estádios III/IV $(R R=2,81)$ foram fatores prognósticos negativos independentes. Conclusões: Estádio avançado e envolvimento linfonodal foram os fatores associados com a pior sobrevida em longo prazo.

INTRODUCTION

C olorectal cancer is the most common type of gastrointestinal cancer. Its cause is multifactorial, including genetic, environmental exposure, diet, and inflammatory conditions of the digestive tract ${ }^{12}$. The incidence and mortality of it had a slight decrease over the past 20 years; however, colon cancer remained the third most common cause of cancer-related mortality in $2014^{2}$. In Brazil, 32,600 new cases were diagnosed in 2013 (15,070 male and 17530 female $)^{16}$.

There are many controversies in the literature about the prognostic value of tumor location ${ }^{23}$. Many studies have shown higher survival rates for tumors 
in the right colon, and worse prognosis as the lesions are located more distally ${ }^{9}$. The standard right colectomy for treatment of malignant tumors consists of en-block removal of the terminal ileum, cecum, ascending colon, hepatic flexure, proximal transverse colon, and their respective lymphovascular drainage and mesenteric lymph nodes. This includes resection of ileocolic and right colic vessels, and eventually the right branch of the middle colic vessels ${ }^{30}$

The aim of this study was to analyze the results of surgical treatment of patients with right colon cancer stages I-IV operated in a period of ten years (2002-2012) and identify prognostic factors that were associated with lower overall survival.

\section{METHODS}

In this series were evaluated the results of surgical treatment of patients with right colon cancer treated in the Service of Colon and Rectal Surgery of the Hospital das Clínicas, School of Medicine of University of São Paulo, São Paulo, Brazil, from 2002 - 2012. Data were collected retrospectively from prospectively collected database. Of 1219 patients treated, a total of 566 patients had colon cancer, and 199 (16.32\%) were in the right colon. Of these, 187 underwent right hemicolectomy with curative intent thus making the total number of patients included in this study.

The following factors were studied: gender, age, tumor location, number of nodes removed in the specimen, lymph node status, $T$ stage and presence of distant metastases. These factors were evaluated for the possibility of prognostic impact in five-year survival.

The bowel preparation was performed on the day before surgery. One liter of $10 \%$ mannitol solution was used for cases scheduled as open procedure, while 90 $\mathrm{ml}$ of sodium phosphate $10 \%$ solution was used for laparoscopic cases to prevent bowel gaseous distension. Intravenous antibiotic prophylaxis was performed $1 \mathrm{~h}$ before the start of operation with cephalosporin of second or third generation alone or combined with metronidazole, and maintained postoperatively for up to $36 \mathrm{~h}$. The thromboembolic prophylaxis was made in all patients with subcutaneous enoxaparin injections.

The patient positioning on the operating table for either laparotomic or laparoscopic right colectomy was supine position with lower limbs opened. For laparoscopic procedures, patients were carefully set on the operating table with bandages and strips to allow intraoperative tilt, such as the Trendelenburg position and lateralization.

\section{Surgical technique}

According to oncologic principles, surgery included en-bloc resection, adequate lymphadenectomy, high ligation of vascular pedicle, and free resection margins. Surgical access was laparotomic or laparoscopic. High ligation of the ileocolyc and right colic vessels were done in all cases $^{30}$. The right colon was mobilized by separating the terminal ileum and cecum of retroperitoneal structures such as the ureter, duodenum and gonadal vessels. At least $10 \mathrm{~cm}$ of terminal ileum was resected in all cases. Transverse colon was transected at least $5 \mathrm{~cm}$ distally to the primary tumor. When tumor was located in the proximal transverse colon, the right branch of the middle colic artery and vein were ligated. Gastrocolic ligament was sectioned and the transverse colon was completely mobilized in order to perform a tension free anastomosis with good blood supply. Ileocolic anastomosis was done manually (end-to-end) or mechanically or side-to-side.

\section{Statistical analysis}

The SPSS software $20.0^{\circledR}$ was used for the analyses of the variables. Patient and tumor characteristics were described with use of estimate measures (mean, standard deviation, and median, minimum and maximum) for quantitative variables. Absolute and relative frequencies were described for qualitative variables (Kirkwood and Sterne, 2006). Mean overall survival time was estimated according to the characteristics of interest using the Kaplan-Meier function (Kleinbaum, 1996); however, it was not possible to estimate the median time because the number of deaths was inferior to $50 \%$. Survival rates between categories were compared using log-rank test (Kleinbaum, 1996). Hazard Ratios (HR) with 95\% confidence intervals were estimated by bivariate Cox regression. Cox multiple regression analyses were used to simultaneously explore the effects of several variables on overall survival (Kleinbaum, 1996). Two models were created: one considering stage $T, N$ and $M$ separately, and other model considering the final stage (TNM) of the tumor. The tests were performed at a significance level of $5 \%$.

\section{RESULTS}

A total of 187 patients underwent right colectomy. Women predominated with $56.1 \%$. There was a higher incidence of patients with 61 years or more (66.8\%), followed by patients with 40 to 60 years old (27.8\%). Ninety (47.5\%) tumors were located at ascending colon, 78 (41.7\%) at cecum, and $20(10.7 \%)$ at hepatic flexure. The median length of hospital stay was 14 days (Table 1 ).

\section{TABLE 1 - Characteristics of patients $(n=187)$}

\begin{tabular}{|l|c|}
\hline Variable & Description \\
\hline Age (years) & \\
\hline Mean (DP) & $65,05(12,11)$ \\
\hline$\quad$ Median (min; max) & $66(31 ; 88)$ \\
\hline Length of stay (days) & $16,64(9,83)$ \\
\hline Mean (DP) & $14(5 ; 60)$ \\
\hline Median (min; max) & \\
\hline Survival time (months) & $38,27(30,85)$ \\
\hline Mean (DP) & $31(0 ; 116)$ \\
\hline Median (min; max) & $105(56,1)$ \\
\hline Gender, $\mathbf{n}(\%)$ & $82(43,9)$ \\
\hline Female & \\
\hline Male & $78(41,7)$ \\
\hline Localization, $\mathbf{n}(\%)$ & $90(48,1)$ \\
\hline Cecum & $19(10,2)$ \\
\hline Ascending colon & Hepatic flexure
\end{tabular}

Of the 187 patients, 86 (45.9\%) had lymph node involvement, 48 (25.6\%) were N1 and 38 (20.3\%) N2. One hundred forty $(74.8 \%)$ of these cases were stage T3. Among those, 68 (48.5\%) were T3N0, 42 (30\%) were T3N1, and 30 (21.4\%) were T3N2. The average number of dissected lymph nodes per patients was 21.6. Of the 24 patients classified as T4, 14 (58.3\%) had no lymph node involvement, four (16.6\%) were $\mathrm{N} 1$ and 6 (25\%) were N2 (Table 2). 
TABLE 2 - Lymph node stage of patients with right colon cancer

\begin{tabular}{|c|c|c|c|c|c|c|c|c|}
\hline \multicolumn{5}{|c|}{ STAGING } & \multicolumn{4}{|c|}{ RIGHT COLECTOMY } \\
\hline \multicolumn{5}{|c|}{$187 / 418$ patients } & \multicolumn{4}{|c|}{ oct/2002-oct/2012 } \\
\hline "T2N" & $\mathrm{N}^{\circ}$ & $\%$ & "T3N" & $\mathrm{N}^{\circ}$ & $\%$ & "T4N" & $\mathrm{N}^{\circ}$ & $\%$ \\
\hline T2NO & 10 & 71,43 & T3NO & 68 & 48,57 & T4NO & 14 & 58,33 \\
\hline T2N1 & 2 & 14,29 & T3N1 & 42 & 30,00 & T4N1 & 4 & 16,67 \\
\hline T2N2 & 2 & 14,29 & T3N2 & 30 & 21,43 & T4N2 & 6 & 25,00 \\
\hline TOTAL & 14 & 100,00 & TOTAL & 140 & 100,00 & TOTAL & 24 & 100,00 \\
\hline \multicolumn{5}{|c|}{ LYMPH NODES DISSECTED } & \multicolumn{2}{|c|}{ MEAN } & \multicolumn{2}{|c|}{ VARIATION } \\
\hline \multicolumn{4}{|l|}{ TOTAL } & & \multicolumn{2}{|c|}{21,67} & \multicolumn{2}{|c|}{$(4-67)$} \\
\hline
\end{tabular}

As for the number of lymph nodes resected, $163(87.2 \%)$ had 12 or more in the surgical specimen, and 86 (46\%) had lymph nodes metastases. Only seven patients (3.7\%) had distant metastases confirmed intraoperatively. One hundred and seventy-one patients (91.4\%) had stage II or III disease. Regarding histological type, 158 (84.5\%) were non mucinous tumors (Table 3).

TABLE 3 - Tumor's characteristics $(n=187)$

\begin{tabular}{|l|c|}
\hline Variable & $\mathbf{n}(\%)$ \\
\hline T, & \\
\hline T1 & $9(4,8)$ \\
\hline T2 & $14(7,5)$ \\
\hline T3 & $140(74,9)$ \\
\hline T4 & $24(12,8)$ \\
\hline N, & $101(54)$ \\
\hline N0 & $86(46)$ \\
\hline N+ & \\
\hline M, & $180(96,3)$ \\
\hline M0 & $7(3,7)$ \\
\hline M1 & $9(4,8)$ \\
\hline Stage & $79(42,2)$ \\
\hline I & $92(49,2)$ \\
\hline II & $7(3,7)$ \\
\hline III & \\
\hline IV & $24(12,8)$ \\
\hline Number of resected lymph nodes & $163(87,2)$ \\
\hline Less than 12 & $158(84,5)$ \\
\hline 12 or more & $29(15,5)$ \\
\hline Histological type & \\
\hline Non mucinous & \\
\hline Mucinous &
\end{tabular}

The 30 day mortality rate was $5.3 \%$ (10 patients). The median length of survival for was 38.3 months. The median five-year survival was $70.9 \%$ (Table 4).

According to the data presented in Table 4, advanced $T$ stage and advanced final stage (TNM stage) statistically correlated with decreased overall survival ( $p=0.027$ and $p<0.001$ respectively), although the Hazard Ratio (HR ) values did not show confidence intervals different than 1 (it was calculated by reference to stage I, in which there were no deaths). The positivity of $\mathrm{N}$ and $\mathrm{M}$ stages resulted in statistically reduced survival time of patients $(p<0.001$ and $p=$ 0.004 , respectively).

The results of a Cox regression model showed that controlling the others patient characteristics, only positivity in stage $\mathrm{N}$ increased the risk of mortality of patients (risk of death increased $106 \%$ in patients with stage $N+, p=0.016$ ) (Table 5).

The majority of patients $(86.8 \%)$ had more than 12 lymph nodes resected. The group of patients with less than 12 showed no significant difference of survival in this study.
TABLE 4 - Estimation of the average survival times of patients according to characteristics of interest and results of the comparative tests

\begin{tabular}{|c|c|c|c|c|c|c|c|c|c|c|}
\hline \multirow{2}{*}{ Variable } & \multirow{2}{*}{ Mean } & \multicolumn{2}{|c|}{$95 \%$ IC } & \multirow{2}{*}{ HR } & \multicolumn{2}{|c|}{$95 \%$ IC } & \multirow{2}{*}{$\begin{array}{c}\text { nof } \\
\text { deaths }\end{array}$} & \multirow{2}{*}{$\begin{array}{c}\text { Total } \\
\mathrm{n}\end{array}$} & \multirow{2}{*}{$\%$} & \multirow{2}{*}{$p$} \\
\hline & & Inf. & Sup. & & Inf. & Sup. & & & & \\
\hline Gender & & & & & & & & & & 0,580 \\
\hline Female & 81,71 & 71,06 & 92,36 & 1,00 & & & 27 & 105 & 25,7 & \\
\hline Male & 76,77 & 65,30 & 88,24 & 1,22 & 0,71 & 2,09 & 25 & 82 & 30,5 & \\
\hline Age (years) & & & & & & & & & & 0,475 \\
\hline 40 or less & 65,96 & 38,07 & 93,85 & 1,00 & & & 4 & 10 & 40,0 & \\
\hline 41 a 60 & 86,01 & 71,97 & 100,05 & 0,56 & 0,18 & 1,74 & 11 & 52 & 21,2 & \\
\hline $\begin{array}{l}\text { More than } \\
60\end{array}$ & 78,04 & 68,34 & 87,74 & 0,71 & 0,25 & 1,98 & 37 & 125 & 29,6 & \\
\hline $\begin{array}{l}\text { Tumor } \\
\text { Location }\end{array}$ & & & & & & & & & & 0,417 \\
\hline Cecum & 78,82 & 66,59 & 91,04 & 1,00 & & & 23 & 78 & 29,5 & \\
\hline $\begin{array}{l}\text { Ascending } \\
\text { colon }\end{array}$ & 79,37 & 68,25 & 90,49 & 1,03 & 0,59 & 1,80 & 26 & 90 & 28,9 & \\
\hline $\begin{array}{l}\text { Hepatic } \\
\text { flexure }\end{array}$ & 86,38 & 73,05 & 99,71 & 0,47 & 0,14 & 1,58 & 3 & 19 & 15,8 & \\
\hline $\mathrm{T}$ & & & & & & & & & & $0,027^{*}$ \\
\hline T1 & 113,00 & 113,00 & 113,00 & 1,00 & & & 0 & 9 & 0,0 & \\
\hline $\mathrm{T} 2$ & 107,67 & 92,76 & 122,58 & 0,55 & 0,03 & 8,84 & 1 & 14 & 7,1 & \\
\hline T3 & 77,95 & 69,01 & 86,89 & 3,19 & 0,42 & 24,14 & 41 & 140 & 29,3 & \\
\hline T4 & 56,14 & 36,79 & 75,48 & 5,48 & 0,67 & 44,77 & 10 & 24 & 41,7 & \\
\hline $\mathrm{N}$ & & & & & & & & & & $<0.001^{*}$ \\
\hline NO & 90,85 & 81,22 & 100,49 & 1,00 & & & 19 & 101 & 18,8 & \\
\hline $\mathrm{N}+$ & 67,15 & 54,97 & 79,32 & 2,52 & 1,44 & 4,40 & 33 & 86 & 38,4 & \\
\hline M & & & & & & & & & & $0,004^{*}$ \\
\hline Negative & 82,27 & 74,27 & 90,27 & 1,00 & & & 47 & 180 & 26,1 & \\
\hline Positive & 34,50 & 0,00 & 69,31 & 3,11 & 1,20 & 8,07 & 5 & 7 & 71,4 & \\
\hline Stage & & & & & & & & & & $<0.001^{*}$ \\
\hline I & 113,00 & 113,00 & 113,00 & 1,00 & & & 0 & 9 & 0,0 & \\
\hline II & 92,36 & 81,81 & 102,92 & 1,49 & 0,19 & 11,44 & 14 & 79 & 17,7 & \\
\hline III & 68,26 & 57,26 & 79,27 & 3,86 & 0,52 & 28,55 & 33 & 92 & 35,9 & \\
\hline IV & 34,50 & 0,00 & 69,31 & 7,68 & 0,89 & 66,01 & 5 & 7 & 71,4 & \\
\hline $\begin{array}{l}\text { Resected } \\
\text { lymph } \\
\text { nodes }\end{array}$ & & & & & & & & & & 0,953 \\
\hline $\begin{array}{l}\text { Less than } \\
12\end{array}$ & 80,60 & 60,61 & 100,60 & 1,00 & & & 7 & 24 & 29,2 & \\
\hline 12 or more & 79,79 & 71,15 & 88,43 & 0,92 & 0,43 & 1,97 & 45 & 163 & 27,6 & \\
\hline $\begin{array}{l}\text { Histological } \\
\text { type }\end{array}$ & & & & & & & & & & 0,383 \\
\hline $\begin{array}{l}\text { Non } \\
\text { mucinous }\end{array}$ & 81,85 & 73,28 & 90,43 & 1,00 & & & 42 & 158 & 26,6 & \\
\hline Mucinous & 69,98 & 51,35 & 88,60 & 1,36 & 0,68 & 2,70 & 10 & 29 & 34,5 & \\
\hline Total & 80,57 & 72,67 & 88,47 & & & & 52 & 187 & 27,8 & \\
\hline
\end{tabular}

TABLE 5 - Results of the Cox regression model with multiple use of $\mathrm{T}$ stage, $\mathrm{N}$ and $\mathrm{M}$

\begin{tabular}{l|c|c|c|c|} 
& & \multicolumn{2}{c}{$95 \%$ IC } & \\
\cline { 3 - 4 } Variable & HR & Inf. & Sup. & p \\
\hline Age (years) & 1,00 & 0,98 & 1,02 & 0,952 \\
\hline Gender (male) & 1,34 & 0,77 & 2,32 & 0,295 \\
\hline T (T3 or T4) & 3,21 & 0,76 & 13,60 & 0,113 \\
\hline N (N+) & 2,06 & 1,14 & 3,70 & 0,016 \\
\hline M (positive) & 2,17 & 0,78 & 6,09 & 0,140 \\
\hline Histological type (mucinous) & 1,46 & 0,71 & 3,02 & 0,305
\end{tabular}

According to the Cox regression model, only the final TNM stage had influenced survival time, whereas patients with stage III or IV showed the risk of death 2.81 times higher than those in stage I or II $(p=0.001)$. The other variables showed no significant difference (Table 6).

TABLE 6 - Results of the Cox regression model with multiple use of the final stage

\begin{tabular}{|c|c|c|c|c|}
\hline \multirow{2}{*}{ Variable } & \multirow{2}{*}{ HR } & \multicolumn{2}{|c|}{$95 \% \mathrm{CI}$} & \multirow{2}{*}{ p } \\
\hline & & Inf. & Sup. & \\
\hline Age (years) & 1,00 & 0,98 & 1,02 & 0,908 \\
\hline Gender (male) & 1,24 & 0,72 & 2,14 & 0,433 \\
\hline Stage (III or IV) & 2,81 & 1,53 & 5,15 & 0,001 \\
\hline Histological type (mucinous) & 1,54 & 0,75 & 3,18 & 0,240 \\
\hline
\end{tabular}


DISCUSSION

This study was done in a tertiary hospital of the State of São Paulo, Brazil. For the purpose of healthcare education, operations were performed by resident physicians in training, always accompanied by a member of colorectal surgeon's staff. The study reflects the importance of colon cancer incidence in the period of a decade in a teaching hospital and analyzes the factors related to survival and mortality of affected patients. Was often refered to colon and rectal cancer as a unique identity, since its epidemiology, etiology and pathogenesis are very similar. However, some characteristics make them quite different. The embryology, histology, regional and topographical anatomy make these very distinct diseases. Therefore, malignancies of these organs have unique biology with separate lines of tumor dissemination and specific anatomic relationships. Their treatments are usually odd and distinct.

In the present study, the incidence of right colon cancer represented $16.3 \%$ of tumors of the large intestine (colon+rectum), which agrees with most literature series ${ }^{1}$. Regarding the location of the tumor in the right colon, the results presented here also agree with the literature, since there was no significant difference between the cecum, ascending colon and hepatic angle distribution, and as the effects on survival of patients ${ }^{11}$. In this series the most affected age group was in the sixth decade of life or more, and it was evenly distributed in both genders ${ }^{9}$.

The median length of hospital stay was 14 days, which is considerable high. However, due to the social issues, patients were routinely submitted to preoperative staging tests after their admission and this usually took some days before surgery. Moreover, many of them had no residence in São Paulo nor had relatives or friends in the city that could host them, requiring prolonged hospital stay in postoperative period for wound care, hygiene and nursing care.

The prognosis of colon cancer is determined by the

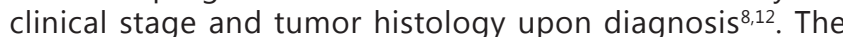
location of the tumor can also be important. Although it is generally accepted that tumors on the right side are associated with the greatest number of resected lymph nodes ${ }^{14}$, the strength of this association is not clear ${ }^{22}$. The American College of Surgeons' National Surgical Quality Improvement Program reported a mortality rate of $4 \%$ after 28,692 colorectal resections, which agrees with the results of this study with the difference that here study was included only right colon cancer ${ }^{20}$. Clearly, not all patients have equal risk of morbidity and mortality; adverse results vary according to the characteristics of the patient, including demographic factors, severity of the disease and comorbidities. In this series, $88 \%$ of patients had stage III and IV, the most advanced disease. Advanced T stage, $\mathrm{N}$, $M$, and the final TNM stage significantly reduced overall survival.

Unlike other studies in the literature, there were no prognostic factors as the number of resected lymph nodes, histological type and evidence of lymphovascular and perineural invasion ${ }^{10}$. The association between high lymph node yield and increased survival may be a marker of quality of surgical technique for cancer resection ${ }^{20}$. The number of lymph nodes evaluated after surgical resection was positively associated with survival of patients with stage II and III. This consideration supports the results of the number of lymph nodes evaluated as a measure of quality of care in the treatment of colon cancer ${ }^{28}$. The results of positivity in stage $\mathrm{N}$ and $\mathrm{M}$ resulted in reduced survival time of patients and were comparable to a review of Surveillance, Epidemiology and End Results (SEER) by AJCC
Taskforce, which showed the worst prognosis for patients with positive lymph node metastasis as was to be expected. In addition, the prognosis for T4a lesions was better than $\mathrm{T} 4 \mathrm{~b}$ by category $\mathrm{N}$. This author also showed that the number of positive lymph nodes affects the prognoses ${ }^{31}$.

The factors that influence obtaining adequate and accurate lymph node staging in patients with colon cancer are not fully understood and may depend on several variables such as the quality of the surgical resection, quality of pathologic evaluation, tumor factors and patient himself ${ }^{24}$. Several studies interested in prognostic factors showed that the five-year survival in patients with lymph node metastases ranges from 0 to $11 \%$, significantly lower than the survival rate of $37-76 \%$ in patients without lymph node involvement ${ }^{26}$.

Another study confirmed that several factors may have an independent effect on survival after surgery for colon cancer, such as the pathologic $\mathrm{T}, \mathrm{N}$ stage, and lymph node yield ${ }^{15}$.

Surgeons who resect a high number of lymph nodes are possibly better able to make more complete resection of the primary tumor, as well as all correspondent lymphovascular tissue. The literature has also shown that teaching hospitals with residency programs, have higher mean number of resected lymph nodes compared to that obtained in hospitals with no residence program ${ }^{18,27}$. The average rate of lymph nodes resected in this study was 21.64 , which is above that found in different papers on literature, which ranged from 7.5 to $15.8^{3,4,6,7,13,17-19,21,25,27}$.

The minimum number of nodes required by the American Joint Committee on Cancer (AJCC) is 12, which is an indicator of surgical quality supported by other studies on colon cancer ${ }^{30}$. Authors emphasize that the presence of lymph node metastases is the most important pathological determinant in survival ${ }^{10,12,24,28,31}$. The importance of the number of resected lymph nodes was an independent and determining factor in survival ${ }^{25}$.

A multicenter study showed that $85 \%$ of recurrences of colon cancer occur within the first three postoperative years, with $95 \%$ occurring within five years. Therefore, these patients should undergo regular surveillance until at least five years after surgery ${ }^{5}$. The average duration of follow-up reported after right colectomy was 22.3 months ${ }^{7,18}$.

For some authors the higher penetration of the tumor in the colon wall is associated with lower survival rates. The presence of lymph nodes affected by cancer is a negative prognostic factor, and consequently higher recurrence and lower survival ${ }^{1,20}$. It should be emphasized that the treatment of this tumor is multidisciplinary; however, oncologic results can only be achieved when the operation complies with the principles of oncological radically, similar to what has been learned from the treatment of rectal cancer $^{27}$. The technique of total excision of mesocolic translates into lower rates of local recurrence and better global survival ${ }^{5}$.

The survival rate at five years for patients with colorectal cancer in the United States is $65 \%{ }^{18,21}$. Survival is inversely related to the stage; patients with stage I have five-year survival of $95 \%$, and those with the III, $60 \%$. In metastatic disease and in stage IV, the survival rate at five years is $10 \%^{18}$. In light of this information, one can say that the results presented here were satisfactory because, although the series is made by $83 \%$ of patients with stages III and IV, the rate of overall survival at five years was $72.2 \%$, and the average length of survival was 38.27 months s, $19,29^{1}$.

To get better results, there is a need to reinforce colorectal cancer screening in our population in order to prevent these unfavorable conditions at initial diagnosis. 


\section{CONCLUSION}

Right-sided colon cancer presented commonly at advanced stage. Advanced stage and lymph node involvement were factors associated with poor long term survival.

\section{ACKNOWLEDGEMENT}

The authors thank Michele Tomitão for her dedication and great effort to collect data that substantiated this study.

\section{REFERENCES}

1. Bilimoria $K Y$, Cohen ME, Ingraham AM, et al. Effect of postdischarge morbidity and mortality on comparisons of hospital surgical quality. Ann Surg 2010; 252(1):183-90.

2. Billeter A, Polk $\mathrm{H}$, Hohmann $\mathrm{S}$, et al. Mortality after elective colon resection: the search for outcomes that define quality in surgical practice. J Am Coll Surg.2012;214:436-443.

3. Braga $M$, Frasson $M$, Zuliani $W$, et al. Randomized clinical tria of laparoscopic versus open left colonic resection. Br J Surg. 2010;97:1180-1186.

4. Buunen M, Veldkamp R, Hop WC, et al. Survival after laparoscopic surgery versus open surgery for colon cancer: long-term outcome of a randomised clinical trial. Lancet Oncol. 2009;10:44-52.

5. Chang GJ, Rodriguez-Bigas MA, Skibber JM, Moyer VA. Lymph node evaluation and survival after curative resection of colon cancer: systematic review. J Natl Cancer Inst 2007; 99: 433-41.

6. Cheung HY, Chung CC, Tsang WW, et al. Endolaparoscopic approach vs conventional open surgery in the treatment ofobstructing left-sided colon cancer: a randomized controlled trial. Arch Surg. 2009:144:1127-1132.

7. Curet MJ, Putrakul K, Pitcher DE, et al. Laparoscopically assisted colon resection for colon carcinoma: perioperative results and long-term outcome. SurgEndosc. 2000;14: 1062-1066.

8. Faivre-Finn C, Bouvier-Benhamiche AM, Phelip JM, Manfredi $\mathrm{S}$, Dancourt V, Faivre J. Colon cancer in France: evidence for improvement in management and survival. Gut2002;51(1):60-4.

9. Farhoud, S; et al. Variáveis clínicas e macroscópicas que influenciam o prognóstico do carcinoma colorretal. Arq. Gastroenterol., Jul 2002, vol.39, no.3, p.163-172.

10. Fielding LP, Phillips RK, Fry JS, Hittinger R (1986) Prediction of outcome after curative resection for large bowel cancer. Lancet 2 (8512):904-907.

11. Guerrieri M, Campagnacci R, De Sanctis A, Lezoche G, Massucco P, Summa M, Gesuita R, Capussotti L, Spinoglio G, Lezoche E. Laparoscopic versus open colectomy for TNM stage III colon cancer: results of a prospective multicenter study in Italy. Surg Today 2012 Nov;42(11):1071-7.

12. Harish K, Narayanaswamy Y, Nirmala S (2004) Treatment outcomes in locally advanced colorectal carcinoma. IntSeminSurgOncol 1(1):8, Nov 4

13. Hewett PJ, Allardyce RA, Bagshaw PF, et al. Short-term outcomes of the Australasian randomized clinical study comparing laparoscopic and conventional open surgical treatments for colon cancer: the ALCCaS trial. Ann Surg. 2008;248:728-738.

14. Hilska M, Gronroos J, Collan Y, Laato M. Surgically treated adenocarcinomas of the right side of the colon during a ten year period: a retrospective study. Ann ChirGynaecol 2001; 215:45-9.
15. Hugen N, van de Velde CJ, de Wilt JH, Nagtegaal ID. Metastatic pattern in colorectal cancer is strongly influenced by histological subtype. Ann Oncol. Mar 2014; 25(3): 651-7.

16. http://www2.inca.gov.br/wps/wcm/connect/tiposdecancer/site/ home/colorretal/

17. Kaiser AM, Kang JC, Chan LS, et al. Laparoscopic-assisted vs. open colectomy for colon cancer: a prospective randomized trial. J LaparoendoscAdvSurg Tech A. 2004;14:329-334.

18. Lacy AM, Garcia-Valdecasas JC, Pique JM, et al. Short-term outcome analysis of a randomized study comparing laparoscopic vs open colectomy for colon cancer. SurgEndosc. 1995:9:1101-1105.

19. Lacy AM, Delgado S, Castells A, et al. The long-term results of a randomized clinical trial of laparoscopy-assisted versus open surgery for colon cancer.Ann Surg. 2008;248:1-7.

20. Le Voyer TE, Sigurdson ER, Hanlon AL, et al. Colon cancer survival is associated with increasing number of lymph nodes analyzed: a secondary survey of intergroup trial INT-0089. J ClinOncol. Aug 1 2003;21(15):2912-9.

21. Liang JT, Huang KC, Lai HS, et al. Oncologic results of laparoscopic versus conventional open surgery for stage II or III left-sided colon cancers: a randomized controlled trial. Ann SurgOncol. 2007:14:109-117.

22. Merkel S, Wein A, Gunther K, Papadopoulos T, Hohenberger W, Hermanek P. High-risk groups of patients with Stage II colon carcinoma. Cancer2001;92(6): 1435-43.

23. Monteiro, ep; et al. Neoplasia colorretal até 40 anos: experiência em cinco anos. Rev bras. colo-proctol., Jun 2006, vol.26, no.2, p.156-161.

24. Panageas KS, Schrag D, Riedel E, Bach PB, Begg CB. The effect of clustering of outcomes on the association of procedure volume and surgical outcomes. Ann Intern Med 2003;139:658-65.

25. Pascual $M$, Alonso $S$, Pares $D$, et al. Randomized clinical trial comparing inflammatory and angiogenic response after open versus laparoscopic curative resection for colonic cancer. $\mathrm{Br}$ I Surg. 2011:98:50-59.

26. Poeze M, Houbiers JG, van de Velde CJ, WobbesTh, von Meyenfeldt MF (1995) Radical resection of locally advanced colorectal cancer. Br J Surg 82(10):1386-1390

27. Stage JG, Schulze S, Moller P, et al. Prospective randomized study of laparoscopic versus open colonic resection for adenocarcinoma. Br J Surg. 1997;84:391-396.

28. Tong Daniel K. H., MBBS, MRCS, WaiLun Law, MS. Laparoscopic Versus Open Right Hemicolectomy for Carcinoma of the Colon. JSLS (2007)11:76-80.

29. Vendramini $D L$, Albuquerque $M M$, Schmidt EM, Rossi-Junior EE, GerentWde A, Cunha VJ. Laparoscopic and open colorectal resections for colorectal cancer.Arq Bras Cir Dig. 2012 AprJun;25(2):81-7.

30. Wolff BG, DW Larson. Right hemicolectomy for treatment of cancer: open technique. In: Fischer JE. Mastery of Surgery. 5th ed. Lippincott, Williams \& Wilkins; 2006:138.

31. Wu Z, Zhang S, Aung LH, Ouyang J, Wei L. Lymph Node Harvested in Laparoscopic Versus Open Colorectal Cancer Approaches: A Metaanalysis. SurgLaparoscEndoscPercutan Tech. 2012 Feb;22(1):5-11. 